\title{
Sistem Pakar Sebagai Alat Bantu Untuk Pendekatan Diagnosis Penyakit Thalasemia Pada Anak Menggunakan Metode Dempster-Shafer
}

\author{
Reza Amelia ${ }^{1}$, Ause Labellapansa ${ }^{2}$, Apri Siswanto ${ }^{3}$ \\ 1,2,3Program Studi Teknik Informatika, Fakultas Teknik, Universitas Islam Riau \\ Jl. Kaharudin Nasution no.113 Marpoyan, Pekanbaru, Indonesia \\ e-mail: ${ }^{1}$ rezaamelia94@gmail.com, ${ }^{2}$ ause.labella@eng.uir.ac.id, \\ 3aprisiswanto@eng.uir.ac.id
}

\begin{abstract}
Thalassemia is one of the congenital blood disorder types. This disease is usually characterized by the condition of red blood cells (eritrosit) which is easily damaged or has shorter life than normal blood cells in general, which is 120 days. This condition is passed on to the child from the parents since the womb. The purpose of this study is to develop an expert system application that can diagnose Thalassemia in children by applying the Dempster Shafer method on diagnosis of symptoms of the disease that accompanies Thalassemia. The Dempster Shafer method is used as a method to calculate the confidence value of the selected symptoms. By comparing each weighting value of the two initial symptoms selected and then comparing the weight value of other symptoms. So as to produce new symptoms that lead to a disease accompanied by the value of the confidence. Implementation of the system with percentage of $76 \%$ indicates that this expert system is able to diagnose early types of Thalassemia disease suffered by children accompanied by the value of confidence and the right solution for the type of illness suffered.
\end{abstract}

Keywords: Dempster Shafer, Thalassemia, Expert System.

\begin{abstract}
Abstrak
Penyakit Thalasemia adalah salah satu jenis penyakit kelainan darah bawaan. Penyakit ini biasanya ditandai dengan dengan kondisi sel darah merah (eritrosit) yang mudah rusak atau lebih pendek umurnya dari sel darah normal pada umumnya, yaitu 120 hari. Kondisi ini diturunkan orang tua kepada anaknya sejak dalam kandungan. Penelitian ini mengembangkan aplikasi sistem pakar yang dapat melakukan diagnosa penyakit Thalasemia pada anak dengan menerapkan metode Dempster Shafer pada proses diagnosa gejala-gejala dari penyakit yang menyertai penyakit Thalasemia. Metode Dempster Shafer digunakan sebagai metode untuk menghitung nilai kepercayaan atas gejala-gejala yang dipilih. Dengan cara membandingkan setiap nilai bobot dari 2 gejala awal yang dipilih untuk seterusnya dibandingkan dengan nilai bobot gejala-gejala lain. Sehingga menghasilkan gejala baru yang mengarah kepada suatu penyakit disertai dengan nilai keyakinannya. Hasil implementasi sistem dengan persentase $76 \%$ menunjukkan bahwa sistem pakar ini mampu mendiagnosa awal jenis penyakit Thalasemia yang diderita oleh anak disertai dengan nilai keyakinan dan solusi yang tepat untuk jenis penyakit yang diderita.
\end{abstract}

Kata Kunci: Dempster Shafer, Penyakit Thalasemia, Sistem Pakar,

\section{PENDAHULUAN}

Kesehatan merupakan hal yang sangat penting bagi manusia, karena siapa saja dapat mengalami ganguan kesehatan begitu pula pada anak baik itu terhadap penyakit 
terutama penyakit genetik ataupun penyakit keturunan. Penyakit genetik yang disebabkan adanya kelainan dalam susunan gen pada seseorang. Adapun salah satu penyakit genetik adalah Thalasemia. Thalasemia adalah salah satu jenis penyakit kelainan darah bawaan. Penyakit ini biasanya ditandai dengan dengan kondisi sel darah merah (eritrosit) yang mudah rusak atau lebih pendek umurnya dari sel darah normal pada umumnya, yaitu 120 hari. Kondisi ini diturunkan orang tua kepada anaknya sejak dalam kandungan [9].

Saat ini masalah penyakit Thalasemia tetap banyak, bahkan akan terus meningkat. Disamping itu penyebab peningkatan kasus penyakit Thalasemia pada anak ini disebabkan rendahnya kesadaran masyarakat untuk melakukan pemeriksaan dan bagaimana cara pengobatan untuk penyakit Thalasemia tersebut. Pada zaman modern sekarang ada sebuah aplikasi yang mempermudah kerja pakar untuk membantu mendiagnosis penyakit Thalasemia yaitu sistem pakar.

Sistem pakar adalah suatu sistem yang dirancang untuk dapat meniru keahlian seorang pakar dalam menjawab pertannyaan dan memecahkan suatu masalah. Dengan bantuan sistem pakar seseorang yang bukan pakar dapat menyelesaikan masalah serta mengambil keputusan yang biasanya di lakukan seorang pakar [5]. Dalam sistem pakar terdapat beberapa metode yang di gunakan salah satunya adalah metode dempster-shafer.

Metode dempster-shafer ditujukan untuk mengetahui diagnosa antara suatu gejala dengan penyakit Thalasemia. Penerapan metode dampster-shafer yang digunakan merupakan variabel berdasarkan nilai ketidakpastian pakar penyakit Thalasemia kemudian dirumuskan menjadi data. Nilai ketidakpastian data pada gejala dan penyakit digunakan sebagai masukan sistem saat melakukan akuisis pengetahuan penyakit oleh pakar menjadi masukan sistem saat melakukan akuisis pengetahun kaidah penyakit. Sistem pakar di buat bukan untuk menggantikan para pakar atau dokter akan tetapi hanya di gunakan untuk alat bantu dalam melakukan diagnosis penyakit.

Terdapat beberapa penelitian yang telah dilakukan sebelumnya, penelitian untuk mendiagnosa penyakit leukima menggunakan metode Dempster-Shafer [3] yang bertujuan untuk mendeteksi dini penyakit leukemia dengan menjawab pertanyaan tentang gejala - gejala penyakit leukemia. Masalah dalam penelitian ini adalah diagnosa penyakit leukemia pada manusia. Metode yang digunakan yaitu metode Dempster-Shefer dan hasil pada penelitian ini layak untuk digunakan kepada pasien mendiagnosa penyakit leukemia dimana $85 \%$ hasil diagnosa sistem sesuai dengan analisa dokter.

Selanjutnya adalah penelitian interaktif pengenalan penyakit thalasemia melalui media android yang digunakan sebagai media informasi tentang penyakit Thalasemia dan bertujuan agar para remaja lebih mengetahui informasi Thalasemia sejak dini sebagai langkah pencegahan penurunan penyakit Thalasemia dalam keluarga. Masalah penelitian ini adalah kurangnya pengetahuan tentang penyakit Thalasemia. Metode yang dibuat dalam penelitian ini adalah pengumpulan data yang akan menentukan tema dan media, sehingga perancanagan aplikasi interaktif dapat tersampaikan dengan baik dan mudah dipahami oleh target audience.

Penelitian senada dengan membangun sistem pakar identifikasi dini penyakit leukimia dengan metode Certainty Factor bertujuan untuk membantu dalam melakukan identifikasi penyakit Leukemia sejak dini. Masalah dalam penelitian ini adalah diagnosa penyakit Leukemia dan metode yang digunakan yaitu metode Certainty Factor dan hasil pada penelitian ini, sistem pakar mendeteksi kanker darah (leukemia) sejak dini secara cepat, tepat, dan akurat. 


\section{METODOLOGI PENELITIAN}

\subsection{Pengumpulan Data}

Dalam melakukan analisa untuk membangun sebuah sistem pakar, sangat diperlukan sebuah data yang benar, dan terbukti keakuratannya. Maka dari itu, untuk mendapatkan data yang benar dan akurat, teknik pengumpulan data dilakukan dengan cara sebagai berikut :

1. Wawancara (interview)

Teknik wawancara adalah cara yang diambil untuk memperoleh data atau informasi dengan bertanya langsung kepada Dokter Spesialis penyakit yang terkait dalam penelitian ini.

2. Studi Pustaka

Mengumpulkan data dengan cara mencari dan mempelajari dari berbagai sumber yang berkaitan dengan masalah yang diteliti dalam penyusunann tugas akhir ini, baik dari internet, buku, jurnal ilmiah dan dari bacaan lain yang dapat dipertanggung jawabkan.

\subsection{Konsep Teori}

Teori yang yang digunakan pada penelitian ini dapat diuraikan sebagai berikut :

\subsubsection{Penyakit Thalasemia}

Thalasemia adalah penyakit herediter (keturunan) yang ditandai dengan gangguan dan ketidakmampuan memproduksi eritrosit dan hemoglobin [1]. Penyakit ini biasanya ditandai dengan dengan kondisi sel darah merah (eritrosit) yang mudah rusak atau lebih pendek umurnya dari sel darah normal pada umumnya, yaitu 120 hari. Kondisi ini diturunkan orang tua kepada anaknya sejak dalam kandungan. [7].

Thalasemia terjadi akibat ketidakmampuan sumsum tulang membentuk protein yang dibutuhkan untuk memproduksi hemoglobin $(\mathrm{Hb})$ secara sempurna. hemoglobin merupakan protein kaya zat besi yang berbeda di dalam sel darah merah (eritrosit) dan berfungsi sangat penting untuk mengangkut oksigen dari paru-paru ke seluruh bagian tubuh yang membutuhkannya.

Secara umum, terdapat 2 (dua) jenis thalasemia, yaitu :

1. Thalasemia Mayor

Thalasemia mayor terjadi pada seseorang yang mempunyai bakat Thalasemia sepenuhnya dan menunjukkan tanda-tanda Thalasemia. Proses transfusi darah diperlukan 3 hingga 4 minggu sekali untuk mendapatkan kadar $\mathrm{Hb}$ yang optimal. Penerimaan darah secara bertahap akan menyebabkan kelebihan zat besi yang berkumpul di dalam tubuh. Kelebihan zat besi ini bisa merusak jantung, hati, dan pancreas, yang mengakibatkan penderita Thalasemia mengalami gangguan pada organ-organ tersebut [1].

2. Thalasemia Minor

Thalasemia minor adalah jenis Thalasemia di mana seseorang mempunyai kecacatan gen Thalasemia, tetapi tidak menunjukkan tanda-tanda Thalasemia atau tandatanda sebagai pembawa sifat. Thalasemia akan terlihat setelah penderita mamasuki gajala awal, seperti lemas, pusing, dan nyeri di bagian perut [1].

\subsubsection{Sistem Pakar}

Istilah sistem pakar berasal dari istilah knowledge-based expert system. Istilah ini muncul karena untuk memecahkan masalah, system pakar menggunakan pengetahuan seorang pakar untuk meningkatkan kemampuan pemecahan masalah, sedangkan seorang pakar menggunakan sistem pakar untuk knowledge assistant [5]

Konsep dasar sistem pakar meliputi enam hal berikut ini :

1. Kepakaran (Expertise)

2. Pakar (Expert) 
3. Pemindahan Kepakaran (Transferring Expertise)

4. Inferensi (Inferencing)

5. Aturan-aturan (Rule)

6. Kemampuan menjelaskan (Explanation Capability)

\subsubsection{Teori Metode Dempster-Shafer}

Secara umum Teori Dempster Shafer ditulis dalam suatu interval :[Belief, Plausibility]. Belief (Bel) adalah ukuran kekuatan evidence dalam mendukung suatu himpunan proposisi. Jika bernilai 0 maka mengindikasikan bahwa tidak ada evidence, dan jika bernilai 1 menunjukkan adanya kepastian. Plausibility $(\mathrm{Pl})$ dinotasikan sebagai :

$$
P l(s)=1-\operatorname{Bel}(\neg s)
$$

Plausibility juga bernilai 0 sampai 1 . Jika kita yakin akan $\neg S$, maka dapat dikatakan bahwa $\operatorname{Bel}(\neg S)=1$, dan $\operatorname{Pl}(\neg s)=0$. Pada teori Dempster Shafer kita mengenal adanya frame of discernment yang dinotasikan dengan $\theta$. Frame ini merupakan semesta pembicaraan dari sekumpulan hipotesis [5].

\section{3 Perancangan Sistem}

\section{3.1 Context Diagram}

Context Diagram adalah suatu diagram yang digunakan untuk mendesain sistem yang memberikan gambaran secara rinci mengenai semua informasi yang diterima ataupun dihasilkan dari suatu aktivitas. Pada Gambar 1 terdapat 2 entitas yaitu tenaga medis dan pakar. Pakar akan memasukkan data penyakit, gejala, kasus dan rule sedangkan tenaga medis akan melakukan input data gejala yang dirasakan pasien untuk dapat memberikan kesimpulan.

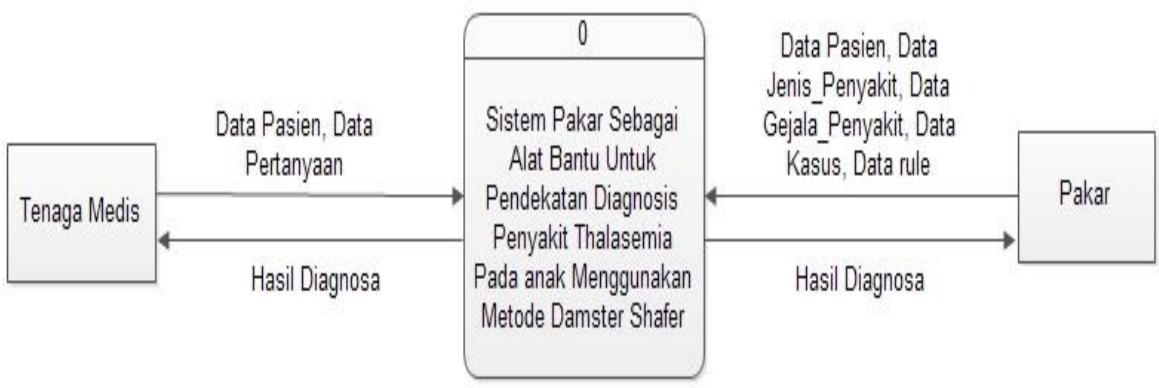

Gambar 1. Context Diagram Sistem Pakar Thalasemia

\section{3.2 Hierarchy Chart}

Hierarchy Chart adalah suatu diagram yang menggambarkan permasalahanpermasalahan yang kompleks diuraikan pada elemen-elemen yang bersangkutan. Berikut adalah gambaran Hierarchy Chart pada Sistem Pakar Sebagai Alat Bantu Untuk Pendekatan Diagnosis Penyakit Thalasemia Pada Anak Dengan Menggunakan Metode Dempster-Shafer, di gambarkan pada Gambar 2 


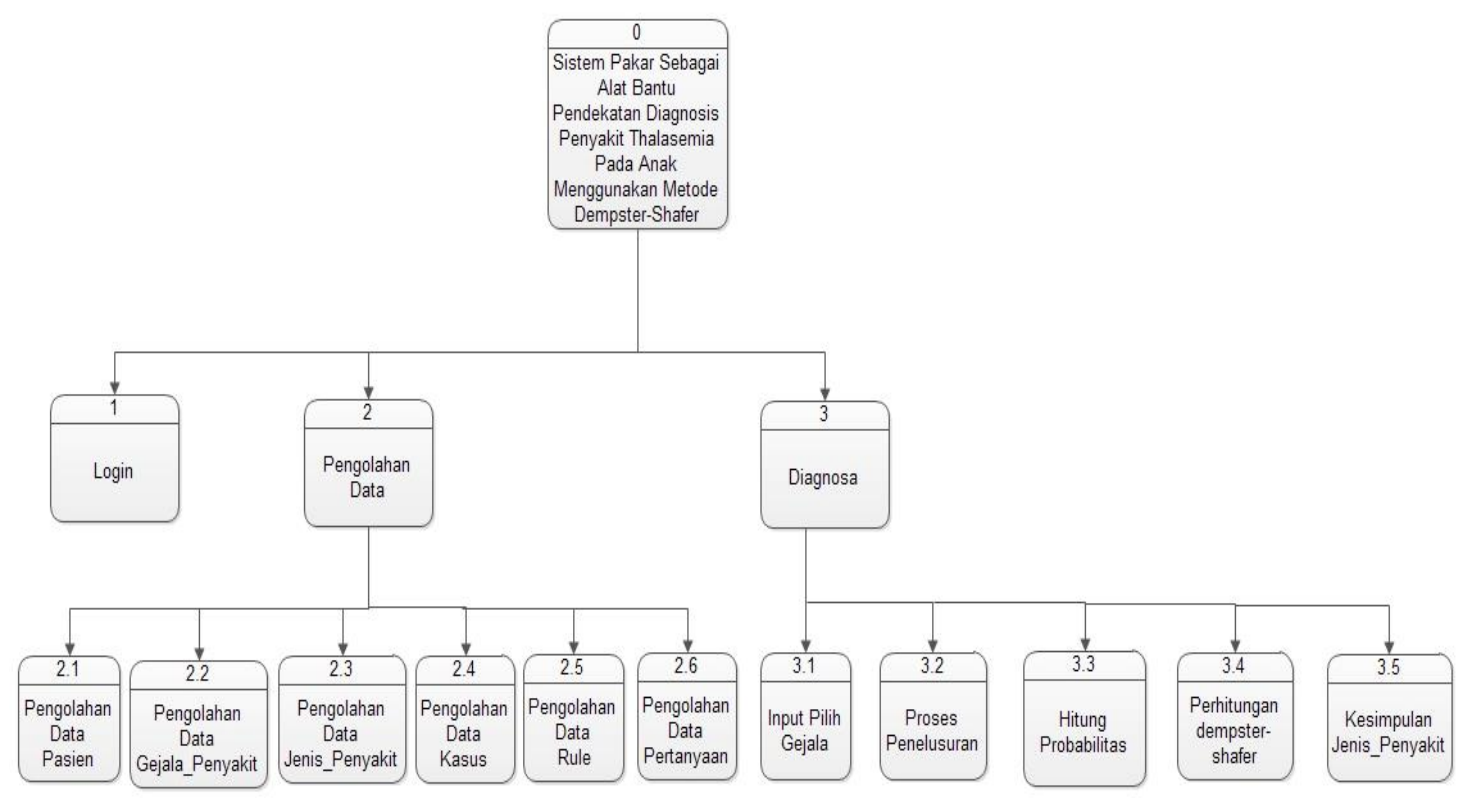

Gambar 2 Hierarchy Chart Sistem Pakar yang Dibangun

\section{3.3 Data Flow Diagram (DFD)}

Data Flow Diagram adalah diagram alur data yang menjelaskan proses-proses yang terjadi pada sistem pakar diagnosa penyakit Thalasemia secara lebih terperinci digambarkan pada Gambar 3.

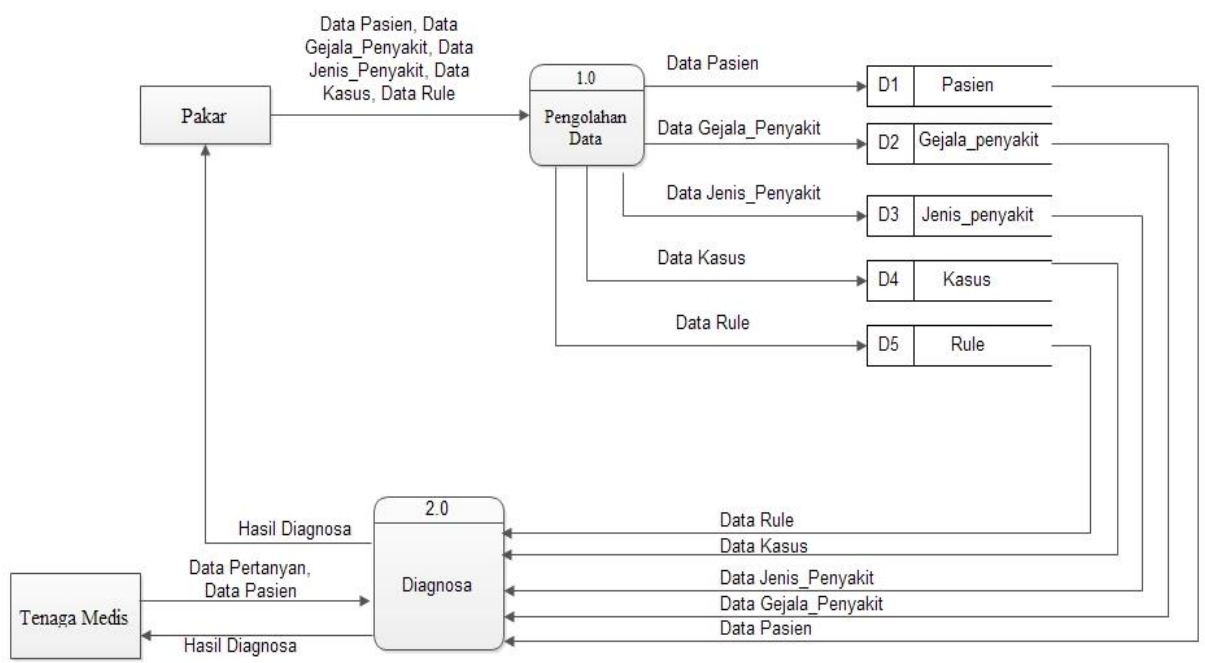

Gambar 3. Flowchart Sistem Pakar yang Dibangun

\section{HASIL DAN PEMBAHASAN}

\subsection{Pengujian Proses Diagnosa Berdasarkan Aturan (Rule)}

Sistem diagnosa penyakit Thalasemia pada anak ini telah diujikan serta dilihat oleh pakar secara langsung, dengan memberikan kasus-kasus yang kemudian diberikan 
kesimpulan diagnosa oleh pakar. Dari hasil wawancara dan referensi, diperoleh 52 gejala dengan 3 penyakit Thalasemia. Adapun untuk memperoleh nilai probabilitas pada Demster-Shafer, digunakan 83 kasus. Tabel 1 merupakan data gejala dan Tabel 2 merupakan data penyakit Thalasemia.

Tabel 1. Data Gejala

\begin{tabular}{|l|l|}
\hline \multicolumn{1}{|c|}{ Kode } & \multicolumn{1}{|c|}{ Gejala } \\
\hline G1 & Pucat \\
\hline G2 & Mual \\
\hline G3 & Demam \\
\hline G4 & Pilek \\
\hline G5 & Lemas \\
\hline G6 & Nafsu Makan Berkurang \\
\hline G7 & Mata Kuning \\
\hline G8 & Mata Cekung \\
\hline G9 & Leher Membesar \\
\hline G10 & Pusing \\
\hline G11 & Tangan Dingin \\
\hline G12 & Sesak Nafas \\
\hline G13 & Mata Sakit \\
\hline G14 & Batuk \\
\hline G15 & Kuku Kaki Biru \\
\hline G16 & Mencret \\
\hline G17 & Nyeri Sendi \\
\hline G18 & Muntah \\
\hline G19 & Kedua Kaki Sakit \\
\hline G20 & Buang Air Kecil Kuning Pekat \\
\hline G21 & Alergi \\
\hline G22 & Sulit Duduk \\
\hline G23 & BAB Warna Hitam \\
\hline G24 & Warna Kulit Kuning \\
\hline G25 & Kuku Jari Biru \\
\hline G26 & Perut Bengkak \\
\hline G27 & Susah Jalan \\
\hline G28 & Pendarahan di Hidung \\
\hline G29 & Pendarahan Gusi \\
\hline G30 & Benjolan di Kepala \\
\hline G31 & Kurang Beraktifitas \\
\hline G32 & Benjolan di Perut \\
\hline G33 & Perut Tegang \\
\hline G34 & Kaki Terasa Pegal \\
\hline G35 & Mata Sembab \\
\hline & \\
\hline
\end{tabular}




\begin{tabular}{|l|l|}
\hline G36 & Sering Mengantuk \\
\hline G37 & Bintik-bintik di Muka \\
\hline G38 & Gatal-gatal di Tangan \\
\hline G39 & Kembung \\
\hline G40 & Gatal-gatal di Perut \\
\hline G41 & Gigi Geraham Kanan Bengkak \\
\hline G42 & Mudah Capek \\
\hline G43 & Nyeri Ulu Hati \\
\hline G44 & Perut Sakit \\
\hline G45 & Perut Terasa Bengkak \\
\hline G46 & Buang Air Kecil Coklat \\
\hline G47 & Sakit Kepala \\
\hline G48 & Jantung Berdetak Kencang \\
\hline G49 & Benonjolan Di Dahi \\
\hline G50 & Turun Berat Badan \\
\hline G51 & Punggung Sakit \\
\hline G52 & Badan Merah-Merah \\
\hline & \\
\hline
\end{tabular}

Tabel 2 Data Penyakit

\begin{tabular}{|c|l|}
\hline Kode Penyakit & \multicolumn{1}{|c|}{ Nama Jenis Penyakit } \\
\hline P1 & Thalasemia Mayor \\
\hline P2 & Thalasemia Beta \\
\hline P3 & Thalasemia Alfa \\
\hline
\end{tabular}

Adapun data kasus yang diuji oleh pakar yaitu berjumlah 3 kasus yang dapat dilihat pada tabel 3 .

Tabel 3. Hasil Diagnosa Pengujian 3 Kasus Terhadap Pakar

\begin{tabular}{|c|c|c|c|c|}
\hline \multirow{3}{*}{ No } & \multirow{3}{*}{ Gejala } & \multicolumn{3}{|c|}{ Hasil Diagnosa Pakar } \\
\hline & & Kasus 1 & Kasus 2 & Kasus 3 \\
\hline & & Thalasemia Mayor & Thalasemia Beta & $\begin{array}{c}\text { Thalasemia } \\
\text { Alfa }\end{array}$ \\
\hline 1 & Pucat & $\mathrm{X}$ & $\mathrm{X}$ & $\mathrm{X}$ \\
\hline 2 & Leher Membesar & $\mathrm{X}$ & - & - \\
\hline 3 & Mata Cekung & - & $\mathrm{X}$ & - \\
\hline 4 & Buang Air Kecil Kuning Pekat & - & - & $\mathrm{X}$ \\
\hline 5 & Pusing & - & - & $\mathrm{X}$ \\
\hline 6 & Warna Kulit Kuning & - & $\mathrm{X}$ & - \\
\hline 7 & Lemas & $\mathrm{X}$ & $\mathrm{X}$ & - \\
\hline 8 & Kuku Jari Biru & - & - & $\mathrm{X}$ \\
\hline 9 & BAB Warna Hitam & - & - & $\mathrm{X}$ \\
\hline 10 & Kurang Beraktifitas & - & $\mathrm{X}$ & - \\
\hline 11 & Tangan Dingin & $\mathrm{X}$ & $X$ & - \\
\hline 12 & Turun Berat Badan & - & $\mathrm{X}$ & $\mathrm{X}$ \\
\hline 13 & Mata Kuning & $\mathrm{X}$ & - & - \\
\hline 13 & Batuk & $\mathrm{X}$ & - & - \\
\hline 14 & Nyeri Ulu Hati & - & - & $\mathrm{X}$ \\
\hline 15 & Badan Merah-merah & - & $\mathrm{X}$ & - \\
\hline 16 & Nyeri Sendi & - & $\mathrm{X}$ & - \\
\hline 17 & Benjolan Di Perut & $\mathrm{X}$ & - & - \\
\hline
\end{tabular}


Gambar 4 dan 5 merupakan tampilan output sistem berdasarkan gejala-gejala yang telah dimasukkan oleh pakar pada pengujian ini. Setelah melihat hasil output pada gambar 3.1, 3.2 dan berdasarkan hasil diagnosa dari pakar pada kasus 1, maka diperoleh kesimpulan bahwa hasil diagnosa dari pakar maupun hasil diagnosa dari sistem memberikan kesimpulan yang sama yaitu Penyakit Thalasemia Mayor dan hasil perhitungan yang dilakukan secara manual dengan perhitungan yang dilakukan oleh sistem pada gambar 3.1 dan 3.2 menunjukan kesimpulan yang sama yaitu Penyakit Thalasemia Mayor dengan tingkat keyakinan terhadap hasil $76.37 \%$.

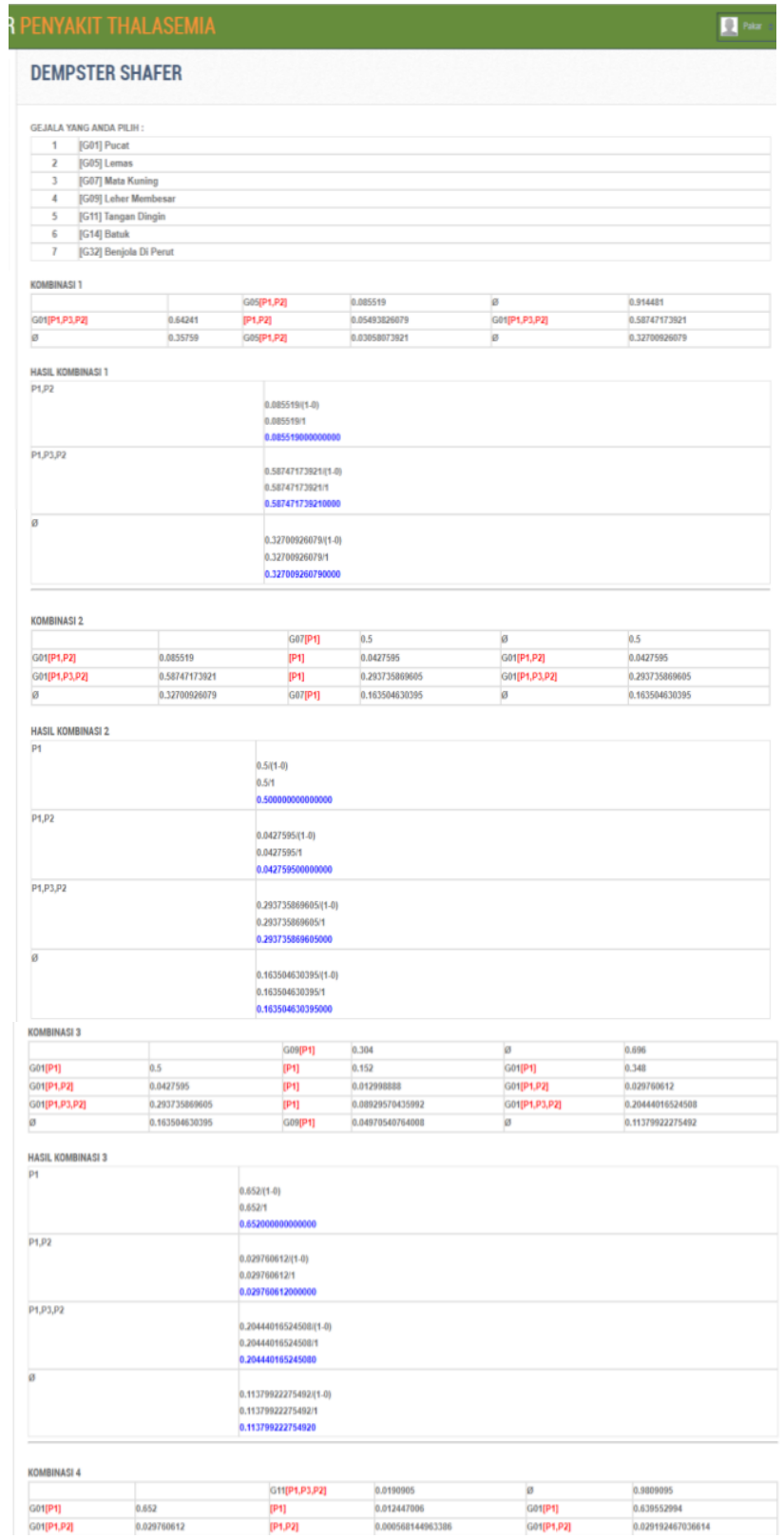

Gambar 4.Tampilan Output Sistem 


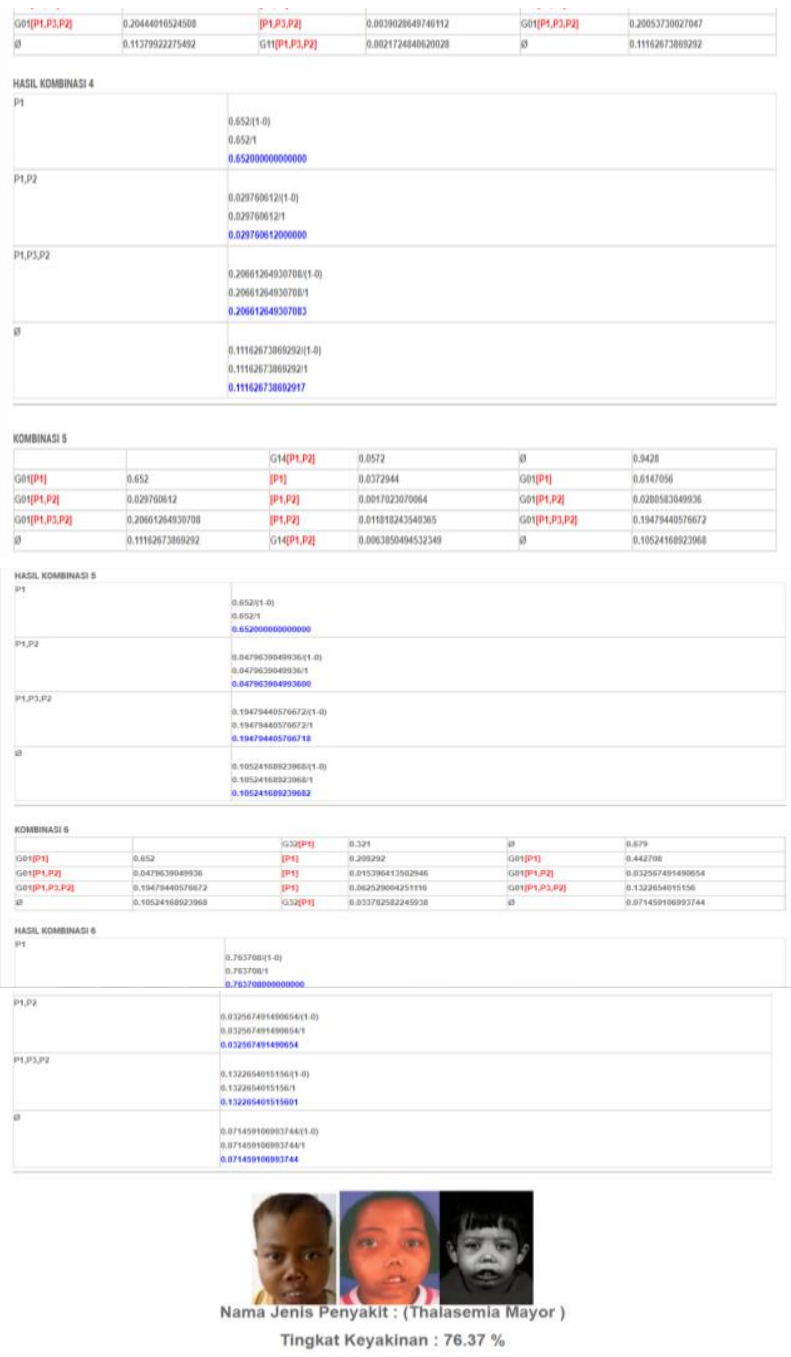

Gambar 5. Tampilan Output Sistem

\section{KESIMPULAN DAN SARAN}

Kesimpulan yang dihasilkan pada penelitian ini adalah telah dihasilkan suatu sistem yang dapat menghasilkan proses diagnosis penyakit Thalasemia pada anak dengan menggunakan metode Dempster Shafer dimana identifikasi penyakit ini menerapkan metode forward chaining karena metode ini merupakan metode yang sama dengan cara dokter pada umumnya untuk diagnosis penyakit Thalasemia pada anak. Untuk penelitian selanjutnya diharapkan dapat melakukan pembaharuan untuk data learning, sehingga akurasi dari pengujian sistem dapat lebih baik lagi. 


\section{DAFTAR PUSTAKA}

[1] Ardinasari., 2016., Buku Pintar Mencegah \& Mengobati Penyakit Bayi \& Anak., Bestari.,Jakarta.

[2] Desiani, Anita., Arhami, Muhammad., 2006,Konsep Dasar Sistem Pakar, Andi, Yogyakarta.

[3] Ditta, Amelia, Diah, Nugroho, Erwin, 2012, Aplikasi Diagnosa Penyakit Leukimia Menggunakan Metode Dempster-shafer Berbasis Web, Jurnal Teknik Informatika, Vol. 1 September 2012.

[4] Kadir, Abdul, 2003, Pemrograman Web Mencakup: HTML, CSS, JAVASCRIPT \& PHP, Andi Offset, Yogyakarta.

[5] Kusumadewi, Sri,. 2003,Artificial Intelligence (Teknik dan Aplikasinya), Graha Ilmu, Yogyakarta.

[6] Ladjamudin, Bin Albahra, 2006, Rekayasa Perangkat Lunak, Graha Ilmu, Yogyakarta

[7] Puspitosari, Heni A, 2013, Desain Web Dinamis dengan PHP dan MySQL, Skripta, Yogyakarta.

[8] Sukri.,2016., Mengenal, Mendampingi \& Merawat Thalasemia, Bee Media Pustaka, Jakarta.

[8] Sutabri, Tata, 2012, Analisis Sistem Informasi, Andi Offset, Yogyakarta.

[9] Sutojo T., dkk.,2011, Kecerdasan Buatan, Andi, Yogyakarta.

[10] Yakub, 2012,Pengantar Sistem Informasi, Graha Ilmu, Yogyakarta. 